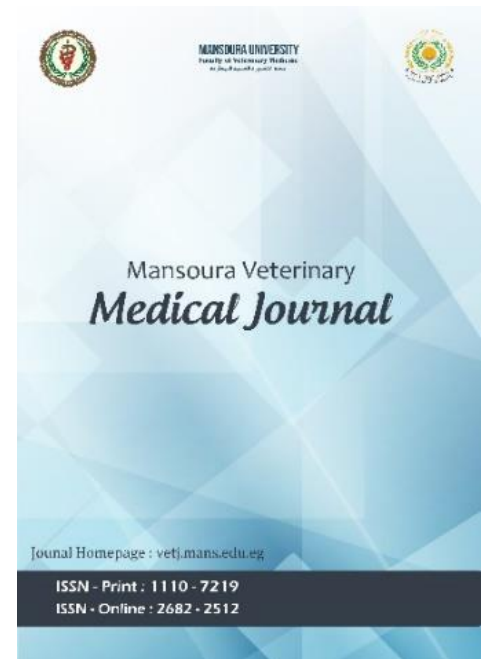

\title{
Prevalence, virulence and antibiotic susceptibility of Listeria monocytogenes isolated from sheep
}

Shimaa Elbar, Rasha Elkenany, Mohamed Elhadidy, Gamal Younis

To cite this article: Shimaa Elbar, Rasha Elkenany, Mohamed Elhadidy, Gamal Younis. Prevalence, virulence and antibiotic susceptibility of Listeria monocytogenes isolated from sheep. Mansoura Veterinary Medical Journal 2020; 21, 2: 48-52.

To link to this article: https://doi.org/10.35943/mvmj.2020.21.2.207

Published online: 25 June 2020

Submit your article to this journal

CrossMark data 


\title{
Prevalence, virulence and antibiotic susceptibility of Listeria monocytogenes isolated from sheep
}

\author{
Shimaa Elbar ${ }^{1}$, Rasha Elkenany ${ }^{1 *}$, Mohamed Elhadidy ${ }^{1,2}$, Gamal Younis $^{1}$
}

${ }^{1}$ Department of Bacteriology, Mycology, and Immunology, Faculty of Veterinary Medicine, Mansoura University, 35516 Mansoura, Egypt

2Zewail City of Science and Technology, University of Science and Technology, Giza, Egypt

ARTICLE HISTORY ABSTRACT

\section{Received: 12.02 .2020 \\ Revised: 26.04 .2020}

Accepted: 28.04 .2020

Address correspondence to Rasha $\mathrm{M}$. Elkenany, PhD; Tel: +201090226696; Email: dr_rashavet22@yahoo.com

\begin{abstract}
Objective: This study was undertaken to determine the prevalence, virulence, and antibiotics susceptibilit of Listeria monocytogenes isolated from hindbrain, spinal cord, milk, and intestinal content collected fror sheep in the Dakahlia Governorate, Egypt.

Design: Observational study.

Samples: We analyzed 472 samples, including 72 hindbrain/spinal cord samples from emergenc) slaughtered sheep, 300 raw-milk samples from apparently healthy sheep, and 100 intestinal content sample from slaughtered sheep at three abattoirs.

Procedures: Isolation and identification of $L$. monocytogenes were performed using conventional technique: The biochemically identified isolates were confirmed by 16SrRNA gene sequencing and examined $\mathrm{fc}$ virulence-associated genes ( $h l y A$ and $i a p)$ as well as for antimicrobial susceptibility.

Results: In total, 16 (3.39\%) out of 472 sheep samples [5.56\% (4/72) in hindbrain/spinal cord, 4\% (12/300) i milk, and $0 \%(0 / 100)$ in intestinal content samples] were found to be positive for $L$. monocytogenes. All th confirmed isolates were positive for the hlyA gene (100\%); meanwhile, none of them exhibited the iap gene Antibiotic susceptibility testing showed high resistance rates to amoxicillin, cefotaxime, erythromycin (50; each), and vancomycin (37.5\%). Sulfamethoxazole-trimethoprim and tetracycline resistance rates were 25 ! and $12.5 \%$, respectively. On the contrary, all isolates were susceptible to amikacin, ciprofloxacin, an norfloxacin. Interestingly, $37.5 \%(6 / 16)$ of $L$. monocytogenes isolates exhibited multidrug resistance (MDR The multiple antibiotic resistances (MAR) index of isolates ranged from 0.1 to 0.6.

Conclusion and clinical relevance: Our data highlights the importance of awareness of virulent strains c MDR L. monocytogenes of sheep samples and potentially samples from other domestic animals in Egypt.
\end{abstract}

Keywords: Listeria monocytogenes; hylA gene; iap gene; virulence; antibiotic susceptibility; sheep.

\section{INTRODUCTION}

Listeria monocytogenes is a facultative intracellular bacterium, that can cause severe food-borne infection in humans and invasive diseases in different animal species, especially in ruminants [1]. L. monocytogenes is widely disseminated in environmental locations including moist soil, the gastrointestinal tract of healthy a nimals, and in feedstuff such a s silage [2, 3]. Lightly acidified silage affords a nexcellent survival and even mul tiplication substrate [4]. It has the ability to survive at low temperatures and $\mathrm{pH}$, excessive salt or bile concentrations, oxidative stress, carbon starvation, and in other hostile environments [5].

In sheep, L. monocytogenes cause various infections, including meningoencephalitis, abortion, neonatal mortality, stillbirth, septicemia, and enteritis [6, 7]; ra rely, listeric myelitis is seen [8]. Somewhere el se, encephalitis, frequently related to silage feeding, is more common [9]. Listeria might be excreted in milk during lactation and the presence of Listeria in milk sa mples is considered to indicate a high risk for contamination of dairy products [10]. Sheep milk has traditionally been recognizedas a likely source of listeriosis [11]. Intermittent shedding of $L$. monocytogenes has also been reported in asymptomatic small ruminants [12].
Several virulence factors in Listeria permit invasion, survival, multiplication, and bacterial mobility in the intracellular environment [13].

Listeriolysin O (LLO), a cholesterol-dependent cytolysin and a pore-forming exotoxin with hemolytic activity $[17,18]$, is encoded by the hly gene. LLO mediates Iysis of bacteriumcontaining phagocytic vacuoles, causing release of $L$. monocytogenes from the phagosome into the cytosol following phagosome acidification. The intracellular mobility and cell-tocell s pread are facilitated by the surface protein actin A (ActA). Act $A$ is res ponsible for intracellular movement through actin polymerization and a lso has a role in cell adhesion and invasion $[14,15]$. Moreover, internalins are surface proteins used in adhesionandentrance to target cells, while phospholipase $C$ and lecithinase are important in mediating membrane lysis [16]. Iva nolysin is a nother cholesterol-dependent cytolysin. Apart from the $h l y$ gene, rel eva nt markers for the identification of $L$. monocytogenes is the iap gene-another important virulence-associated gene in L. monocytogenes, which encodes a surface protein with murein hydrolase activity.

Quick, specific, and sensitive diagnostic methods able to differentiate L. monocytogenes from other Listeria s pecies are essential for efficient control of the listeriosis. As $L$. monocytogenes exhibit strain variations in virulence and pathogenicity, the ability to identify potentially pathogenic strains of $L$. monocytogenes precisely and quicklyis necessa ry 
to limit the spread of L. monocytogenes infection and reduce food-related diseases $[\mathbf{1 9}, \mathbf{2 0}]$. Accordingly, polymera se chain reaction (PCR) assays have been developed for identification of virulent strains of $L$. monocytogenes isolated from the brain stem and silage and associated with outbreaks in sheep [21, 22].

Listeria species are generally sensitive to numerous antibiotics; however, drug-resistant strains are emerging in food products [23]. Antimicrobial resistance in Listeria strains is caused by the horizontal transfer of a ntimicrobial resistance genes and genetic interchange between different Listeria species [24, 25]. L. monocytogenes is commonly susceptible to antimicrobial agents with an effect on Gram-positive bacteria. However, within the last decades the drug resistance has emerged in L. monocytogenes [24].

Although L. monocytogenes causes losses in Egyptian sheep herds and might be associated with food-borne diseases, L. monocytogenes has been studied only to a very limited extent in Egypt. Cons equently, the current study was undertaken to screen the for the presence of $L$. monocytogenes in samples of hindbrain and spinal cord, milk and intestinal content collected from sheep in the Dakahlia province in Egypt and to determine the virulence and antimicrobial susceptibility in identified isolates.

\section{MATERIALS AND METHODS}

\subsection{Samples}

A total of 472 samples, including 72 hindbrain and spinal cord samples from emergency-slaughtered sheep with or without neurologicals igns from three abattoirs located in Aga, Tonamel, and Mansoura, 300 raw-milk samples from asymptomatic sheep reared at different farms in Sonbokht, Aga, and Alderis, and 100 intestinal content samples from slaughtered sheep in abattoirs were collected from the Dakahlia province in Egypt over the period lasting from November 2016 to April 2017. All samples were collected in sterile packages under a septic conditions, kept on ice during trans portation, and transferredimmediately to the laboratory for microbiological analysis.

\subsection{Isolation and identification of L. monocytogenes}

For bacterial isolation, $25 \mathrm{~g}$ or $\mathrm{mL}$ of each sample was inoculated into $225 \mathrm{~mL}$ of Listeria enrichment broth (Oxoid,
England)containing Listeria-selective enrichment supplement, then homogenized using a stomacher for $30 \mathrm{~s}$, and incubated at $30{ }^{\circ} \mathrm{C}$ for $48 \mathrm{~h}$. A loopful from the previously incubated broth was cultured onto Listeria-selective agar (Oxoid, England) with Listeria-selective supplement and incubated at $37^{\circ} \mathrm{C}$ for 24 48h [26]. Five colonies showing typical morphological characters of Listeria were picked up and subjected to Gram staining, catalase test, cold enrichment, andlaboratory testing for hemolytic activity and CAMP reaction on $5 \%$ sheep blood agar, motilitytesting, and a cid production from sugar [27, 28].

\subsection{Molecular characterization of L. monocytogenes}

DNAs from the isolated L. monocytogenes strains were subtype to PCR assays targeting the 165 rRNA gene and the virulence-associated genes $h / y A$ and iap. The DNAs were extracted by the boiled lysate method [29]. DNA amplification was performed using the primers and conditions listed in Table 1. The amplified DNA products were separated by electrophoresis on $1.5 \%$ agarose gels and photographed by a gel documentation system. DNA from the reference strain $L$. monocytogenes ATCC 35152 was included in the testing as a positive control.

\subsection{Determination of antibiotic susceptibility}

L. monocytogenes isolates were tested for antibiotic susceptibility a gainst nine different antibiotics by the sta ndard disk diffusion method [30] using Mueller-Hinton agar plates (Difco). The following antimicrobial disks (Oxoid) were used:

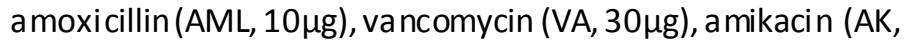
$30 \mu \mathrm{g})$, ciprofloxacin (CIP, $5 \mu \mathrm{g})$, norfloxacin (NOR, 10 $\mu \mathrm{g}$ ), tetra cycline $(T E, 30 \mu \mathrm{g})$, cefotaxime $(C T X, 30 \mu \mathrm{g})$, erythromycin $(\mathrm{E}, 15 \mu \mathrm{g})$, and sulfamethoxazole-trimethoprim (SXT, 25 $\mu \mathrm{g}$ ). Resistance was detected by measuring the inhibition zone around the antimicrobial disk in accordance with the CLSI standards [30]. The reference strain L. monocytogenes ATCC 35152 was applied as a control. AMAR index was determined for each isolate by using the formula MAR = A-B, with (A) indicating the number of antibiotics to which the examined is olate depicted resistance and (B) being the total number of antibiotics to which the examined isolate was evaluated for susceptibility [31].

\subsection{Statistical Analysis}

Statistical a nalysis of the results by calculation of the ratio was made using the SPSS Statistics 17.0 software program.

Table 1. Oligonucleotide primer sequences used in this study.

\begin{tabular}{|c|c|c|c|c|c|c|c|c|}
\hline \multirow[t]{2}{*}{ Target } & \multirow[t]{2}{*}{ Sequence } & \multirow{2}{*}{$\begin{array}{l}\text { Amplified } \\
\text { product }\end{array}$} & \multirow{2}{*}{$\begin{array}{l}\text { Primary } \\
\text { denaturatio } \\
\mathbf{n}\end{array}$} & \multicolumn{3}{|c|}{ Amplification (35 cycles ) } & \multirow{2}{*}{ Final extension } & \multirow{2}{*}{ Reference } \\
\hline & & & & $\begin{array}{l}\text { Secondary } \\
\text { denaturation }\end{array}$ & Annealing & Extension & & \\
\hline $16 S$ rRNA & $\begin{array}{l}\text { GGACCGGGGCTAATACCGAAT GATAA } \\
\text { TTCATGTAGGCGAGTTGCAGCCTA }\end{array}$ & $1200 \mathrm{bp}$ & $94^{\circ} \mathrm{c} / 5 \mathrm{~min}$ & $94 / 30 \mathrm{sec}$ & $\begin{array}{l}60^{\circ} \mathrm{c} / \\
1 \mathrm{~min}\end{array}$ & $72^{\circ} \mathrm{c} / 1 \mathrm{~min}$ & $\begin{array}{l}72^{\circ} \mathrm{C} / 12 \\
\min \end{array}$ & [44] \\
\hline hlyA & $\begin{array}{l}\text { GCATCTGCATTCAATAAAGA } \\
\text { TGTCACTGCATCTCCGTGGT }\end{array}$ & $174 \mathrm{bp}$ & & & $\begin{array}{l}50^{\circ} \mathrm{C} / \\
30 \\
\mathrm{sec}\end{array}$ & $72^{\circ} \mathrm{c} / 30 \mathrm{sec}$ & $\begin{array}{l}72^{\circ} \mathrm{c} / 7 \\
\min \end{array}$ & {$[45]$} \\
\hline Iap & $\begin{array}{l}\text { CTGCTTGAGCGTTCATGTCTCATC CCCC } \\
\text { CATGGGTTTCACTCTCCTTCTAC }\end{array}$ & $131 \mathrm{bp}$ & & & $\begin{array}{l}60^{\circ} \mathrm{c} / \\
30 \mathrm{sec}\end{array}$ & $72^{\circ} \mathrm{c} / 30 \mathrm{sec}$ & $\begin{array}{l}72^{\circ} \mathrm{c} / 7 \\
\min \end{array}$ & {$[46]$} \\
\hline
\end{tabular}




\section{RESULTS}

\subsection{Prevalence of L. monocytogenes in sheep and virulence- associated genes}

In total, 16 (3.39\%) of 472 sheep samples were found positive for L. monocytogenes. All the 16 biochemically identified strains of $L$. monocytogenes were confirmed by PCR (Figure 1). Specifically, the proportion of samples positive for $L$ monocytogenes was $5.56 \%(4 / 72), 4 \%(12 / 300)$, and $0 \%$ $(0 / 100)$ in hindbrain/spinal cord, milk, and intestinal content samples, respectively.

Moreover, all 16 isolates were examined for the two virulence-associated genes $h l y A$ and iap. The $h l y A$ gene was present in $100 \%(16 / 16)$ of the isolates (Figure 2), while the iap gene was absent (Figure $\mathbf{3}$ ).

Table 2. Antibiotic susceptibility of Listeria monocytogenes strains $(n=16)$ from sheep samples.

\begin{tabular}{llll} 
Antibiotic disk & $\begin{array}{l}\text { Susceptible } \\
(\%)\end{array}$ & $\begin{array}{l}\text { Intermediat } \\
(\%)\end{array}$ & Resistant (\%) \\
\hline Amoxicillin & $8(50 \%)$ & 0 & $8(50 \%)$ \\
Vancomycin & $4(25 \%)$ & $6(37.5 \%)$ & $6(37.5 \%)$ \\
Amikacin & $16(100 \%)$ & 0 & 0 \\
Ciprofloxacin & $16(100 \%)$ & 0 & 0 \\
Norfloxacin & $16(100 \%)$ & 0 & 0 \\
Tetracycline & $2(12.5 \%)$ & $12(75 \%)$ & $2(12.5 \%)$ \\
Cefotaxime & $8(50 \%)$ & 0 & $8(50 \%)$ \\
Erythromycin & $8(50 \%)$ & 0 & $8(50 \%)$ \\
Sulfamethoxazole-trimethoprim & $12(75 \%)$ & 0 & $4(25 \%)$
\end{tabular}

Table 3. Antibiotic resistance pattern and multiple antibiotic resistance index among Listeria monocytogenes isolates $(n=16)$ from sheep.

\begin{tabular}{lll} 
Isolate No. & Antibiotic resistance pattern & MAR index \\
\hline 1 & AML,E,SXT & 0.3 \\
2 & AML, VA, CXT, E & 0.4 \\
3 & CXT & 0.1 \\
4 & TE & 0.1 \\
5 & AML & 0.1 \\
6 & VA, E & 0.2 \\
7 & AML, VA, CTX, E, SXT & 0.6 \\
8 & CTX & 0.1 \\
9 & AML, VA, CTX, E & 0.4 \\
10 & CTX & 0.1 \\
11 & AML & 0.1 \\
12 & TE & 0.1 \\
13 & VA, E & 0.2 \\
\hline 15 & AMX & 0.1 \\
\hline 14 & AML, E, SXT & 0.6 \\
\hline & AMA, E, SXT & 0.3 \\
\hline
\end{tabular}

AML: Amoxicillin, VA: Vancomycin, AK: Amikacin,CIP: Ciprofloxacin, NOR: Norofloxacin,TE: TetracyclinE, CTX: Cefotaxime, E: Erythromycin, SXT: Sulfamethoxazole-trimethoprim,

MAR index: Multiple antibiotic resistance index.

\subsection{Antimicrobial susceptibility results}

Resul ts from antimicrobial susceptibility tes ting are shown in Table 2. High resistance rates to amoxicillin, cefotaxime, erythromycin (50\% each), and vancomycin (37.5\%) were observed. Resistance to sulfamethoxazole-trimethoprim and tetracycline was present in $25 \%$ and $12.5 \%$ of the isolates, respectively. On the contrary, all strains were susceptible to a mi ka cin, ciprofloxacin, and norfloxacin. Interestingly, 37.5\% $(6 / 16)$ of the L. monocytogenes isolates were MDR, displaying resistance to more than two classes of a ntibiotics, displaying seven resistance patterns. The MAR index of the strains ranged from 0.1 to 0.6 (Table 3).

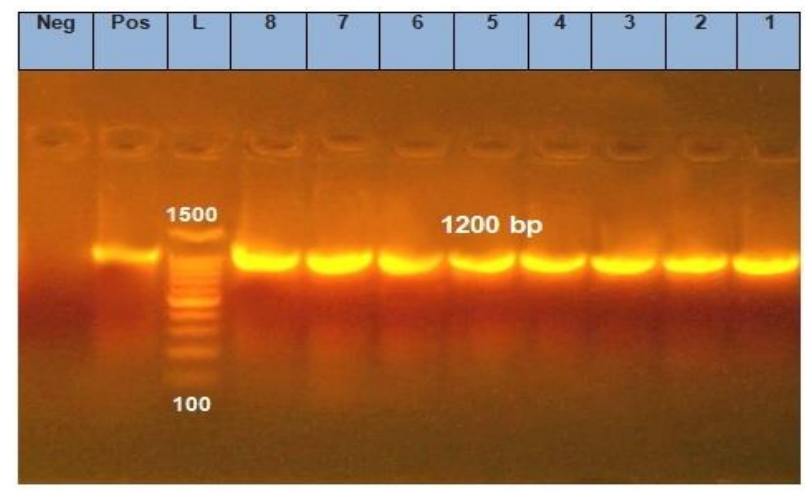

Figure 1. Representative agarose gel electrophoresis of Listeria monocytogenes showing a mplification for 16srRNA gene (1200 bp). (L) ladder $100 \mathrm{bp}$; lane (1-8): positive samples. Neg (negative control), Pos (positive control).

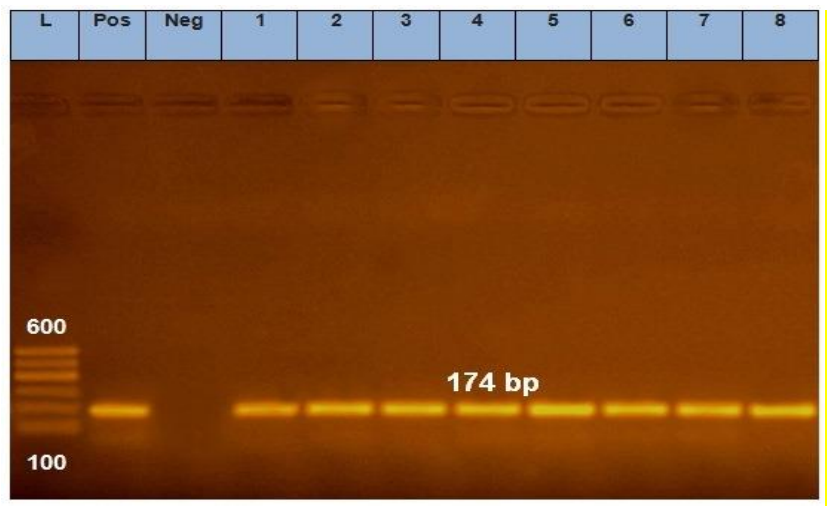

Figure 2. Representative agarose gel electrophoresis of Listeria monocytogenes showing amplification for hylA gene (174 bp). (L) ladder $100 \mathrm{bp}$; lane (1-8): positive samples. Neg (negative control), Pos (positive control).

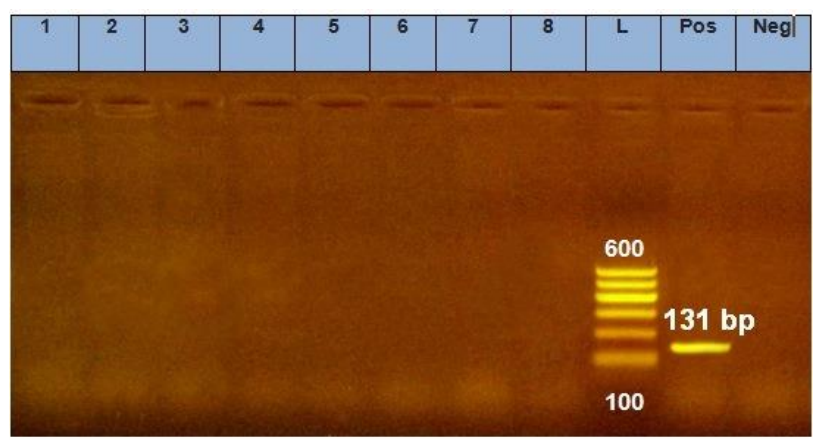

Figure 3. Representative agarose gel electrophoresis of Listeria monocytogenes showing amplification for iap gene (131 bp). (L) ladder 100 bp; lane (1-8): negative samples. Neg (negative control), Pos (positive control). 


\section{DISCUSSION}

L. monocytogenes is the causal agent of listeriosis, affecting a wide range of mammalian species, including monogastric animals, ruminants, and humans. Among ruminants, sheep are commonly affected by L. monocytogenes infection, which may be associated with various clinical presentations, including meningoencephalitis a nd mastitis [3234]. In the present study, we applied 16S rRNA gene PCR as a confirmatory tool for i dentification of $L$. monocytogenes. Alow detection rate of L. monocytogenes (3.39\%, 16/472) was observed in this panel of sheep samples. Four hindbrain/spinal cord sa mples (5.56\%) were positive. Similarly, Aldabbagh [35] identified two out of $50(4 \%)$ isolates in sheep brain samples. In the present work, $12 / 300$ (4.0\%) of the milk samples were found positive. This result was consistent with previous studies where $L$. monocytogenes was detected in $2.5 \%$ and $3.9 \%$ from raw milk and sheep milk in Europe and Egypt, res pectively [36, 37]. The results in the current investigation indicate a low likelihood of contamination related to the occurrence of $L$. monocytogenes in raw sheep milk. Moreover, the absence of $L$ monocytogenes in sheep feces in this study is compatible with a previous study, which reported a very low prevalence $(0.58 \%)$ of L. monocytogenes in sheep feces [38]. In contrast, Wesley [39] noted a higher fecal shedding of $L$. monocytogenes in sheep (8\%). Fecal shedding of Listeria usuallylast for 10 days with Listeria diffusing over the entire volume of the fore-stomach within $4 \mathrm{~h}$, and throughout the whole gastrointestinal tract within $24 \mathrm{~h}$ [40].

With regard to virulence genes, corresponding results were obtained in an ea rlier investigation, where the hylA gene was shown to exist in nearly all of the tested $L$. monocytogenes strains; however, no iap gene was identified [43]. On the contrary, Osman et al. [37] found both of the tested virulence-associated genes (hlyA and iap) in $L$. monocytogenes isolated from sheep milk. Surveillance of such virulence-associated genes in L. monocytogenes strains is critical to identify and discriminate hyper-virulent from less virulent strains.

With regard to antimicrobial susceptibility tests, the resistance of $L$. monocytogenes isolates to cefotaxime, sulfamethoxazole-trimethoprim, and tetracycline was previously reported in Egypt $[37,43]$, indicating the necessity of the continuous monitoring of antimicrobial susceptibility of L. monocytogenes from different sources. Meanwhile, full susceptibility of all isolates to amikacin, ciprofloxacin, and norfloxacin was observed in a previous study [37]. In the present study, $37.5 \%$ of $L$. monocytogenes isolates exhibited MDR. These results could indicate that the evolution of multidrug-resistant strains of $L$. monocytogenes is associated with extensive and perhaps inexpedient usage of antibiotics as a growth promoter in for example farm animals. MDR in Listeria is not unprecedented [24]. The existence of virulenceassociated gene (hlyA gene) in drug-resistant $L$. monocytogenes could increase the difficulty in treating animals suffering from $L$. monocytogenes infection.

Pathogens with a MAR index value below 0.2 would typically come from a lower-hazard source, while those with an
MAR index value higher than 0.2 indicated would typically come from a higher-risk source and reflect inappropria te use of these antibiotics in the surrounding area.

\section{Conclusion}

From this study, we investigated the prevalence of virulent and multidrug-resistant $L$. monocytogenes isolated from hindbrain/spinal cord, milk, and fecal samples collected from sheep in the Dakahlia province in Egypt. The awareness of drug-resistant pathogens should be increased in Egypt, where intensive and inexpedient utilization of antimicrobial agents may bea critical issue. It is necessary for humans to sustain appropriate hygienic measures and pasteurization of milk of sheep to minimalize the risk of infection with $L$. monocytogenes.

\section{Acknowledgment}

\section{Conflict of interest statement}

No conflict of interest.

\section{Research Ethics Committee Permission}

The current res earch workis permitted to be executed according to standards of Res earch Ethics committee, Fa culty of Veterinary Medicine, Mansoura University.

\section{Authors' contribution}

Gamal A. Younis designed the experiment and revised the manuscript. Gamal A. Younis, Mohamed Elhadidy, Rasha M. Elkenany supervised incarrying out the practical part. Rasha $M$. Elkenany shared in writing the paper and took the responsibility of correspondence to the journal. Shimaa.W.A. Elbarcollected samples and carried out the practical part. All authors approved the final version of the manuscript for publication.

\section{REFERENCES}

[1]. Mead PS, Slutsker L, Dietz V, McCaig LF, Bresee JS, Shapiro C, et al. Food-Related IIIness and Death in the United States. Emerg Infect Dis 1999;:607-25. https://doi.org/10.3201/eid0505.990502

[2]. Wiedmann M, Arvik T, Bruce JL, Neubauer J, Smith MC, Hurley J, et al. Investigation of a listeriosis epizootic in sheep in New York state. JAVMA 1997;58(7):733-7.

[3]. Pal A, Labuza TP, Diez-Gonzalez F. Comparison of primary predictive models to study the growth of Listeria monocytogenes at low temperatures in liquid cultures and selection of fastest growing ribotypes in meat and turkey product slurries. Food Microbiol. 2008;25:460-70. https://doi.org/10.1016/j.fm.2008.01.009

[4]. Mitscherlich E, Marth EH. Microbial Survival in the Environment. Germany: Springer Berlin Heidelberg; 1984. https://doi.org/10.1007/978-3-642-69974-0

[5]. Wu S, Wu Q, Zhang J, Chen M, Yan Za, Hu H. Listeria monocytogenes Prevalence and Characteristics in Retail Raw Foods in China. PLOS ONE 2015;10:e0136682. https://doi.org/10.1371/journal. pone.0136682

[6]. Glastonbury JRW. Listeriosis. Sheep Medicine. University of Sydney: Proceedings No. 141 of the Post Graduate Committee in Veterinary science; 1990. p. 470-1.

[7]. Wiedmann M, Mobini S, Cole JJR, Watson CK, Jeffers GT, Boor KJ. Molecular investigation of a listeriosis outbreak in goats caused by an unusual strain of Listeria monocytogenes.JAVMA 1999;215:369-71.

[8]. Seaman JT, Carrigan MJ, Cockram FA, Carter GI. An outbreak of listerial myelitis in sheep. Austral Vet J 1990;67:142-3. https://doi.org/10.1111/j.1751-0813.1990.tb07733.x 
[9]. Zachary JF. Nervous System. In: McGavin MD, Zachary JF, Mosby, editors. Pathological Basis of Veterinary Disease, 4th Edition. St Louis: Elsevier; 2007. p. 877-8.

[10]. Farber JM, Peterkin PI. Listeria monocytogenes, a food-borne pathogen. Microbiol Rev1991;55:476-511. https://doi.org/10.1128/MMBR.55.3.476-511.1991

[11]. Grønstø| H. Listeriosis in sheep. Listeria monocytogenes excretion and immunological state in healthy sheep. Acta vet Scand 1979;20:168-79.

[12]. Conly JM, Johnston BL. Listeria:A Persistent Food-Borne Pathogen. Can J Infect Dis Med 2008;19:327-8. https://doi. org/10.1155/2008/702565

[13]. Radostits OM, Gay CC, Hinchcliff KW, Constable PD. Veterinary Medicine, 10th Edition. Edinburgh: Saunders Elsevier; 2007.

[14]. Suarez M, Gonzalez-Zorn B, Vega Y, Chico-Calero I, Vazquez-Boland JA. A role for ActA in epithelial cell invasion by Listeria monocytogenes. Cell Microbiol 2001;3:853-64. https://doi.org/10.1046/j.1462 5822.2001.00160.x

[15]. Travier L, Guadagnini S, Gouin E, Dufour A, Chenal-Francisque V, Cossart $\mathrm{P}$, et al. ActA promotes Listeria monocytogenes aggregation, intestinal colonization and carriage. PLoS pathogens. 2013;9:1-16. https://doi.org/10.1371/journal.ppat.1003131

[16]. Hirsh CD, Maclachlan JN, Walklers LR. Veterinary Microbiology, 2nd ed. USA: Blackwell publishing; 2004.

[17]. Groves RD, Welshimer HJ. Separation of pathogenic from apathogenic Listeria monocytogenes by three in vitro reactions. J Clin Microbio 1977;5:559-63.

[18]. Thomas EJ, King RK, Burchak J, Gannon VP. Sensitive and specific detection of Listeria monocytogenes in milk and ground beef with the polymerase chain reaction. Appl Environ Microbiol 1991;57:2576-80. https://doi. org/10.1128/AEM.57.9.2576-2580.1991

[19]. Liu D. Characterization of virulent and avirulent Listeria monocytogenes strains by PCR amplification of putative transcriptional regulator and internalin genes. J Med Microbiol 2003;52:1065-70. https://doi.org/10.1099/jmm.0.05358-0

[20]. Roche SM, Gracieux P, Albert I, Gouali M, Jacquet C, Martin PMV, et al. Experimental Validation of Low Virulence in Field Strains of Listeria monocytogenes. Infect Immun 2003;71:3429-36. https://doi.org/10.1128/IAI.71.6.3429-3436.2003

[21]. Wiedmann M, Czajka J, Bsat N, Bodis M, Smith MC, Divers TJ, et al. Diagnosis and epidemiological association of Listeria monocytogenes strains in two outbreaks of listerial encephalitis in small ruminants. J Clin Microbiol 1994;32:991-6. https://doi.org/10.1128/JCM.32.4.991996.1994

[22]. Headley SA, Fritzen JTT, Queiroz GR, Oliveira RAM, Alfieri AF, Di Santis $\mathrm{GW}$, et al. Molecular characterization of encephalitic bovine listeriosis from southern Brazil.Trop Anim Health Prod 2013;46:19-25. https://doi.org/10.1007/s11250-013-0441-0

[23]. Davis JA, Jackson CR. Comparative Antimicrobial Susceptibility of Listeria monocytogenes, L. innocua, and L. welshimeri. Microb Drug Resist 2009;15(1):27-32. https://doi.org/10.1089/mdr.2009.0863

[24]. Charpentier E, Courvalin P. Antibiotic Resistance in Listeriaspp.Antimicrob. Agents Chemother 1999;43(:2103-8. https://doi.org/10.1128/AAC.43.9.2103

[25]. Zhang Y, Yeh E, Hall G, Cripe J, Bhagwat AA, Meng J. Characterization of Listeria monocytogenes isolated from retail foods. Int. J. Food Microbiol

2007;113:47-53. https://doi.org/10.1016/j.ijfoodmicro.2006.07.010

[26]. Lovett J. Taxonomy and general characteristics of Listeria spp. In: Miller AL, Smith JL, A SG, editors. Foodborne listeriosis. Amsterdam: Elsevier Science Publishers; 1990. p. 9-12.

[27]. Allerberger F. Listeria: growth, phenotypic differentiation and molecular microbiology. FEMS Immunol Med Mic 2003;35:183-9. https://doi.org/10.1016/S0928-8244(02)00447-9
[28]. Quinn PJ, Markey BK, Leonard FC, Hartigan P, Fanning S, Fitzpatrick E. Veterinary microbiology and microbial disease, second edition. In: Quinn BK, Markey FC, Leonard ES, Fitzpatrick S, Fanning, Hartigan PJ, editors. LTD: Black well publishing; 2011

[29]. Witham PK, Yamashiro CT, Livak KJ, Batt CA. A PCR-based assay for the detection of Escherichia coli Shiga-like toxin genes in ground beef. Appl Environ Microbiol 1996;62:1347-53. https://doi.org/10.1128/AEM.62.4.1347-1353.1996

[30]. CLSI. Performance Standards for Antimicrobial Susceptibility Testing. twenty first Informationa Supplement. CLSI document M100-S21. Wayne, PA, 2011.

[31]. Krumperman PH. Multiple antibiotic resistance indexing of Escherichia coli to identify high-risk sources of fecal contamination of foods. App Environ Microbiol $1983 ; 46: 165-70$ https://doi.org/10.1128/AEM.46.1.165-170.1983

[32]. Rebhun WC. Diseases of dairy cattle: Williams \& Wilkins; 1995. 410-3

[33]. Fthenakis GC, Saratsis P, Tzora A, Linde K. Naturally occurring subclinical ovine mastitis associated with Listeria monocytogenes. Small Rumin Res 1998;31:23-7. https://doi.org/10.1016/S0921 4488(98)00118-7

[34]. Brugère-Picoux J. Ovine listeriosis. Small Rumin Res 2008;76:12-20. https://doi.org/10.1016/j.smallrumres.2007.12.022

[35]. Aldabbagh S. Diagnostic study for Listeria monocytogenes isolated from brain and meat of sheep in Mosul city. IJVS 2019;33:51-5. https://doi.org/10.33899/ijvs.2019.163087

[36]. Kasalica A, Vukovic V, Vranjes A, Memisi N. Listeria monocytogenes in milk and dairy products. Biotechnol Anim Husb 2011;27:1067-82. https://doi.org/10.2298/BAH1103067K

[37]. Osman KM, Zolnikov TR, Samir A, Orabi A. Prevalence, pathogenic capability, virulence genes, biofilm formation, and antibiotic resistance of Listeria in goat and sheep milk confirms need of hygienic milking conditions. Pathog Glob Health 2013;108:21-9. https://doi.org/10.1179/2047773213Y.0000000115

[38]. Kalender H. Detection of Listeria monocytogenes in faeces from chickens, sheep and cattle in Elazığ province. Turk J Vet Anim Sci 2002;27:449-51.

[39]. Wesley IV. Listeriosis in animals. In: Ryser ET, Marth EH, editors. Listeria listeriosis and food safety, 2nd ed. New York, N.Y: Marcel Decker, Inc; 1999. p. 39-73.

[40]. Zundel E, Bernard S. Listeria monocytogenes translocates throughout the digestive tract in asymptomatic sheep. J Med Microbiol 2006;55(12):1717-23. https://doi.org/10.1099/jmm.0.46709-0

[41]. Vazquez-Boland JA, Kuhn $M$, Berche $P$, Chakraborty $T$, DominguezBernal G, Goebel W, et al. Listeria Pathogenesis and Molecular Virulence Determinants. Clin Microbiol Rev 2001;14:584-640. https://doi.org/10.1128/CMR.14.3.584-640.2001

[42]. Kathariou S. Listeria monocytogenes Virulence and Pathogenicity, a Food Safety Perspective. J Food Prot 2002;65:1811-29. https://doi.org/10.4315/0362-028X-65.11.1811

[43]. Abd El Tawab A, Hassan W, El- Hofy F, Zaki H. Phenotypic and genotypic characterization of listeria species isolated from chicken and milk products. BVMJ 2018;34:94-105. https://doi.org/10.21608/bvmj.2018.53531

44]. Kumar A, Grover S, Batish VK. Exploring specific primers targeted against different genes for a multiplex PCR for detection of Listeria monocytogenes. 3 Biotech 2015; 5:261-269. https://doi.org/10.1007/s13205-014-0225-x

[45]. Deneer HG, Boychuk I. Species-Specific Detection of Listeria monocytogenes by DNA Amplification. Appl Environ Microbiol; 1991; 606-609. https://doi.org/10.1128/AEM.57.2.606-609.1991

[46]. Soni DK, Singh M, Singh DV, Dubey SK. Virulence and genotypic characterization of Listeria monocytogenes isolated from vegetable and soil samples. BMC Microbiol 2014; 14:241. https://doi.org/10.1186/s12866-014-0241-3 